\title{
Enhancement of Overall Equipment Effectiveness using Total Productive Maintenance in a Manufacturing Industry
}

\author{
S.NALLUSAMY ${ }^{1 *}$ and GAUTAM MAJUMDAR ${ }^{2}$ \\ ${ }^{1}$ Professor and Dean, Department of Mechanical Engineering, Dr. M G R Educational \\ and Research Institute, Chennai, 600095, Tamilnadu, India \\ ${ }^{2}$ Professor, Department of Mechanical Engineering, Jadavpur University, Kolkata-032
}

(Received on October 25, 2016, Revised on January 18, 2017)

\begin{abstract}
The current levels of competition makes the organizations to continually strive to meet the customer demand but it has been observed that due to problems like machine breakdown, machining and setting process delays it has become difficult in meeting this on time. The objective of this article is to inspect the manufacturing losses arising on account of such problems by prioritizing the root causes with the help of a pareto diagram and finally suggesting the solution to overcome these problems. A case study was carried out to improve the utilization of machine tool and manpower by initiating the practices through, TPM that would also form as a base for lean manufacturing. TPM helps to adopt a systematic work inside the shop floor which reduces the losses in production activity, increases the equipment life, ensures effective utilization of equipments and organized employee behavior. Introduction of new fixture reduces the idle time of machine during component setting and achieving cycle time reduction by analyzing cutting tool and its parameters which helps to increase the output to meet the customer demand. From the final results, it was observed that there was reduction in setup time, cycle time, breakdown losses and rework time, while the overall equipment effectiveness was also found to have increased by about $15 \%$.
\end{abstract}

Keywords: Manufacturing, TPM, OEE, Cycle Time, Setup Time

\section{Introduction}

As the industries have been trying to minimize their operational costs, there has been maximization of usage of their assets. Production efficiency and effectiveness of these industries depends more on the equipment effectiveness employed. Overall equipment effectiveness (OEE) is seen to be the fundamental way of measuring performance efficiency. An attempt was made to find out the OEE of all the machines and equipment during April 2016 in a CNC manufacturing industry located at Chennai, India. The observed OEE showed various time losses that occurred in the equipment during different processes and the recurring reduction in overall output. In order to meet the customer demand, the OEE metrics were analyzed and solutions were found out for all major losses. Total Productive Maintenance (TPM) being a continual improvement on effectiveness of equipment and processes where all employees are involved, the autonomous maintenance concept being a part of TPM was introduced for maintaining equipment and to follow a systematic procedure in shop floor activity. As the component size being huge it was observed that, the setting takes more time. Therefore, in order to reduce the component setup time by stopping the machine, a new fixture was introduced to do the setup activity 
outside of the machine using FARO instrument. This helped the component to be kept ready for loading once the running component got completed. Similarly, since cycle time also plays a major role in component output, a common tool for drilling, chamfering and counter boring operations which reduces the cycle time considerably was also introduced. From OEE metrics, as it was found that the rework also creates a major time loss. Hence, all the reworks that had happened during April 2016 were studied and analyzed and also appropriate preventive actions for improving the quality performance were taken to reduce this time loss.

\section{Literature Review}

The concept of TPM provides quantitative metric OEE for measuring the effectiveness of equipment in production line. TPM is an exceptional method which is developed from preventive maintenance concept for plant maintenance and management. The actions of TPM eliminate the equipment related losses and improve availability, performance rate and quality rate. Through proper implementation of TPM the OEE value gets increased [1-3]. Just in Time (JIT) and Total Quality Management (TQM) is closely tied and is an extension of Preventive Maintenance (PM) where the machines work at high productivity and efficiency. The fundamental concept of TPM is, if you properly maintain plant machinery there will be a sharp decline in machine breakdowns, safety and quality problems. It needs the development of a preventative maintenance program for the lifecycle of equipment and involvement of operators in maintaining the equipment in order to maximize its overall efficiency and effectiveness [4, 5]. Also it is closely related to the maintenance of all employee responsibility and focus to take necessary preventive action for the expected problem before it occurs [6, 7]. There is emerging need for TPM implementation in Indian manufacturing industries and need to develop TPM implementation practice and procedures. A new definition of performance ratio was introduced to reduce the limitation of cycle time and hence the OEE has been improved [8]. The OEE was improved with low machine breakdown, less idling and minor stop time, less quality defects, reduced accident in plants, increased productivity rate, optimized process parameters, worker involvement, improved profits through cost saving method, increased customer satisfaction and increased sales and also improved employee morale and confidence $[9,10]$. TPM is widely used to measure the efficiency of a manufacturing plant in terms of availability, performance and quality to identify the major productivity losses [11]. An analysis was carried out in CNC shop to calculate the OEE percentage and necessary recommendations were given to enhance the efficiency of the CNC shop floor by eliminating three OEE losses such as downtime, speed loss and quality loss $[12,13]$. The successful applications of motion and time study in manufacturing industries are dependent on the training of the individual employees, who apply it and also highlight the OEE improvement of the autoclave process through the implementation corrective actions [14-16]. Overall Performance Effectiveness (OPE) measurement was an effective way to analyze the efficiency of a single setup process $[17,18]$. The influences of flexible and rigid TQM practices in small and medium scale industries were investigated and broad overviews of how TQM practices were constructed for various quality improvements were studied. Productivity improvement is achieved through eliminating un-necessary movements by use of standard operating procedure, reducing 
cycle time and providing appropriate solutions to various problems during the assembly of components to improve productivity and OEE [19-22]. Various theoretical models were proposed to facilitate the industries for having better understanding about TPM techniques and step by step implementation to improve their productivity [23, 24]. Based on the above literature, an attempt was made to implement the TPM techniques in a windmill component manufacturing industry specifically in the CNC machine shop of Star Engineering located at Chennai. This TPM implementation is to improve the level of quality and reduce the manufacturing cost of the product there by increasing the overall equipment effectiveness of the industry.

\section{Problem Definition and Methodology}

The Industry chosen for the study does the job of machining operations of windmill parts such as rotor hub and bedplates and hence the study specifically focuses on issues in CNC machining operations. In the existing process it was found that the machining cost and cycle time of component to be moderately high. The company was found facing many problems through unexpected machine breakdown and more often they were not able to achieve the customer demand of 6 components per day. In order to correct the systems that were followed in the existing production line TPM practices were suggested for better productivity and OEE. A TPM tool was used to measure performance before and after TPM implementation. OEE when measured was found to be less than 65\%. As OEE helps in monitoring and improving the efficiency of a manufacturing process, this article presents a systematic way to identify the root causes for the low OEE and arrives at a solution in tackling the bottleneck problems by implementing TPM practices.

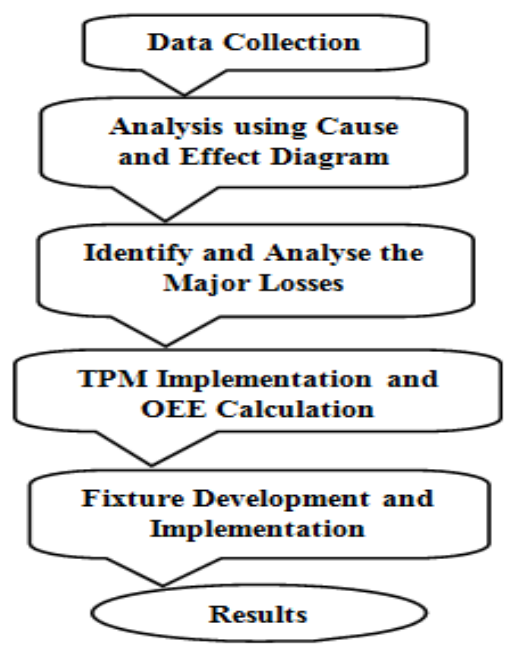

Figure 1: Methodology Flow Chart

The methodology flow chart for the research is shown in Figure 1. The case company found difficulty in competing with other players in the industry but did not know the exact reasons. Hence the study started with detailed collection of data of as existing and a further analysis of the problems were studied. Based on the existing data, the analysis was carried out using cause and effect diagram. The major losses were located through Pareto 
chart for identifying opportunities to change. As the industry had not been practicing any of the TPM techniques, it was suggested to implement the same and was implemented to mitigate the issues in the existing system. A new fixture and tool was developed to reduce the setup time as well. After implementing the TPM technique the results were collected and compared with the existing data.

\section{Data Collection and Analysis}

All the production activity in the CNC machine shop was closely monitored for the month of April 2016. The everyday output was recorded and is shown in Figure 2. The individual machine losses were also identified and noted down.

$$
\mathrm{OEE}=\text { Availability }(\mathrm{A}) \times \text { Performance }(\mathrm{P}) \times \text { Quality }(\mathrm{Q})
$$

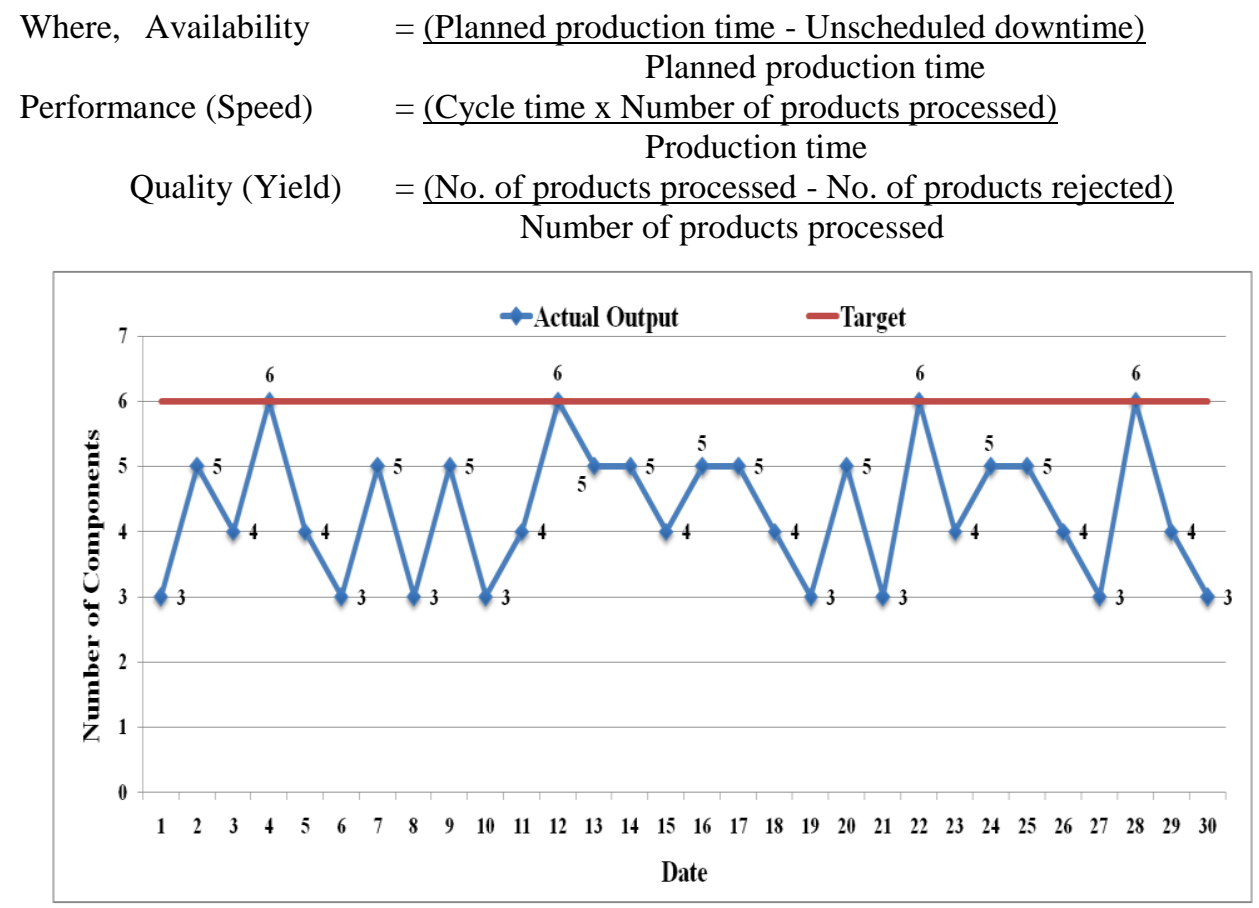

Figure 2: Output for the Month of April 2016

Based on the collected data OEE was calculated for all the individual VMC and HMC machines for the Month of April 2016 and their measurement is shown in Figure 3. From the calculated value it was found that the maximum OEE was around $60 \%$ only.

\subsection{Component Cycle Time}

The component cycle time was noted using stop watch for every operation. It starts from loading the component in the machine and till unloading of the component from the machine. The total cycle time for each component and respective operation is shown in Table 1. 


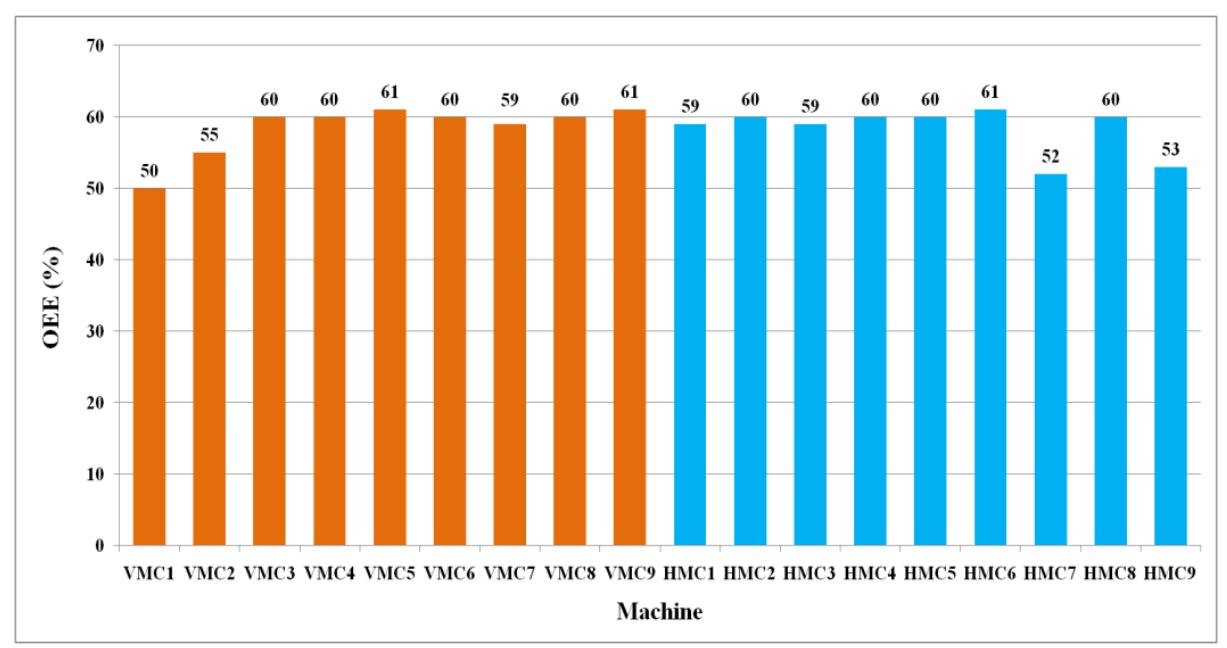

Figure 3: OEE of VMC and HMC for the Month of April 2016

Table 1: Cycle Time for Individual Component

\begin{tabular}{|c|c|c|}
\hline Name of the Component & Operation & Total Cycle Time in Hours \\
\hline Mainframe & First & 35 \\
\hline Mainframe & Second & 27 \\
\hline Hub & First & 33 \\
\hline Hub & Second & 14 \\
\hline E Hub & First & 43 \\
\hline E Hub & Second & 11 \\
\hline Bedplate & First & 29 \\
\hline Bedplate & Second & 35 \\
\hline
\end{tabular}

\subsection{VMC and HMC Machine Setup}

Based on the cycle time of every component the VMC machine was allocated for the first operation and the second operation to meet customer requirement. The machine allocated for first and second operation and the output of each machine is shown in Table 2. Similarly based on the component cycle time, the HMC machine was allocated for first operation and second operation to meet the customer demand. The machine allocated for first and second operation and the output of each machine is shown in Table 3.

Table 2: VMC Machine Setup and Output

\begin{tabular}{|c|c|c|c|}
\hline Machine & First Operation & Second Operation & Output (Pieces) \\
\hline VMC 1 & & MF & 1 \\
\hline VMC 2 & & E BP & 1 \\
\hline VMC 3 & & MF & 1 \\
\hline VMC 4 & MF & & 1 \\
\hline VMC 5 & MF & & 1 \\
\hline VMC 6 & MF & & 1 \\
\hline VMC 7 & & MF & 1 \\
\hline VMC 8 & E BP & & 1 \\
\hline VMC 9 & MF & & 1 \\
\hline
\end{tabular}


Table 3: HMC Machine Setup and Output

\begin{tabular}{|c|c|c|c|}
\hline Machine & First Operation & Second Operation & Output (Pieces) \\
\hline HMC 1 & & Hub & 2 \\
\hline HMC 2 & Hub & & 1 \\
\hline HMC 3 & Hub & & 1 \\
\hline HMC 4 & Hub & & 1 \\
\hline HMC 5 & E Hub & & 1 \\
\hline HMC 6 & E Hub & & 1 \\
\hline HMC 7 & & E Hub & 2 \\
\hline HMC 8 & Hub & & 1 \\
\hline HMC 9 & & Hub & 2 \\
\hline
\end{tabular}

\subsection{Component Output per Day in VMC and HMC}

The component output is based on number of machines allocated for each operation (first operation and second operation) and the output of Mainframe and E Bedplate in VMC machines and the output of Hub and E Hub in HMC machines are shown in Table 4.

Table 4: VMC and HMC Machine Output per Day

\begin{tabular}{|c|c|c|c|}
\hline Machine & Component & First Operation & Second Operation \\
\hline \multirow{2}{*}{ VMC } & Mainframe & 3 & 2 \\
\cline { 2 - 4 } & E Bedplate & 1 & 1 \\
\hline \multirow{2}{*}{ HMC } & Hub & 3 & 3 \\
\cline { 2 - 4 } & E Hub & 1 & 2 \\
\hline
\end{tabular}

\subsection{Sample OEE Analysis}

From the collected data, the OEE analysis was carried out for all the machines of VMC and HMC for the month of April 2016. The model graphical representation of OEE for fifth VMC machine is shown in Figure 4.

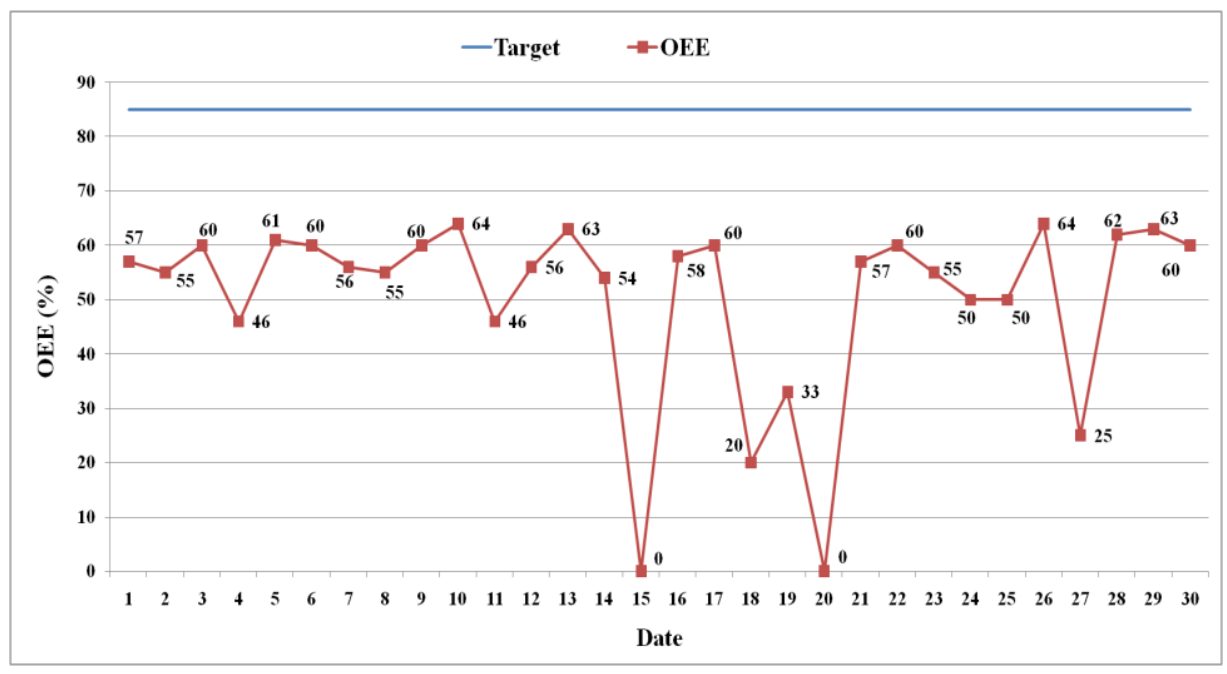

Figure 4: OEE of Fifth Machine 


\subsection{Fishbone Diagram}

The development of cause and effect diagram is to highlight the problem occurred during the OEE measurement. The cause and effect diagram for low OEE is shown in the above Figure 5.

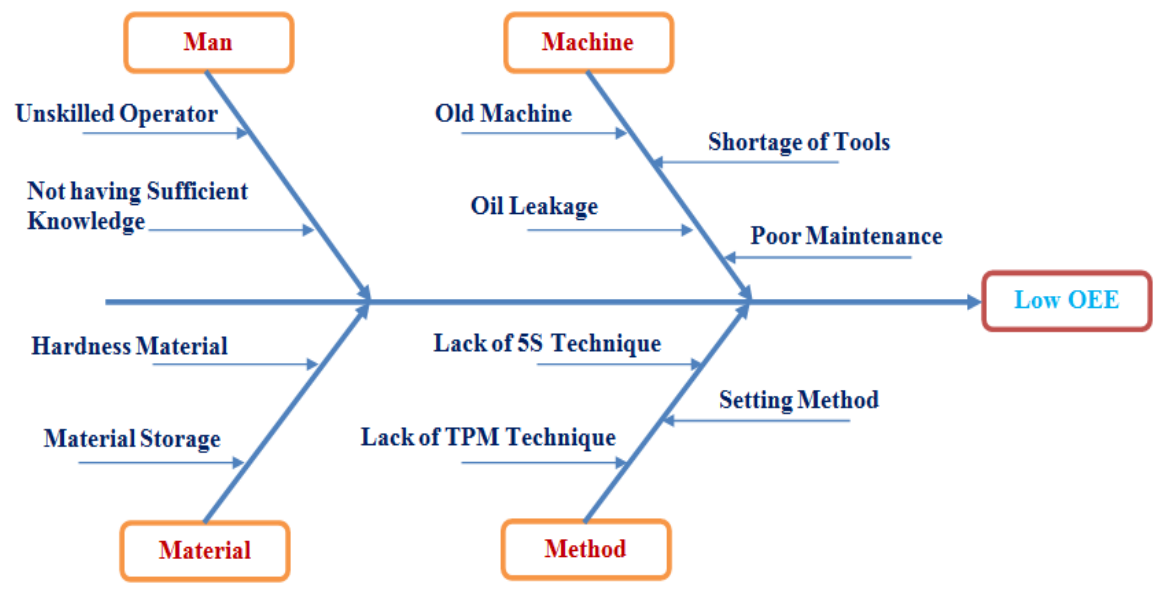

Figure 5:Cause and Effect Diagram for Low OEE

\subsection{Identification of Major Losses}

During the measurement of OEE it was found that various losses had occurred and among these the major losses were identified by using Pareto diagram. Pareto principle says $80 \%$ of the problem is caused by $20 \%$ of the cause. The Pareto chart for various time losses during different operations are shown in Figure 6. From the Pareto chart, it was found that the machining delay, machine breakdown, setup delay and rework were the major losses.

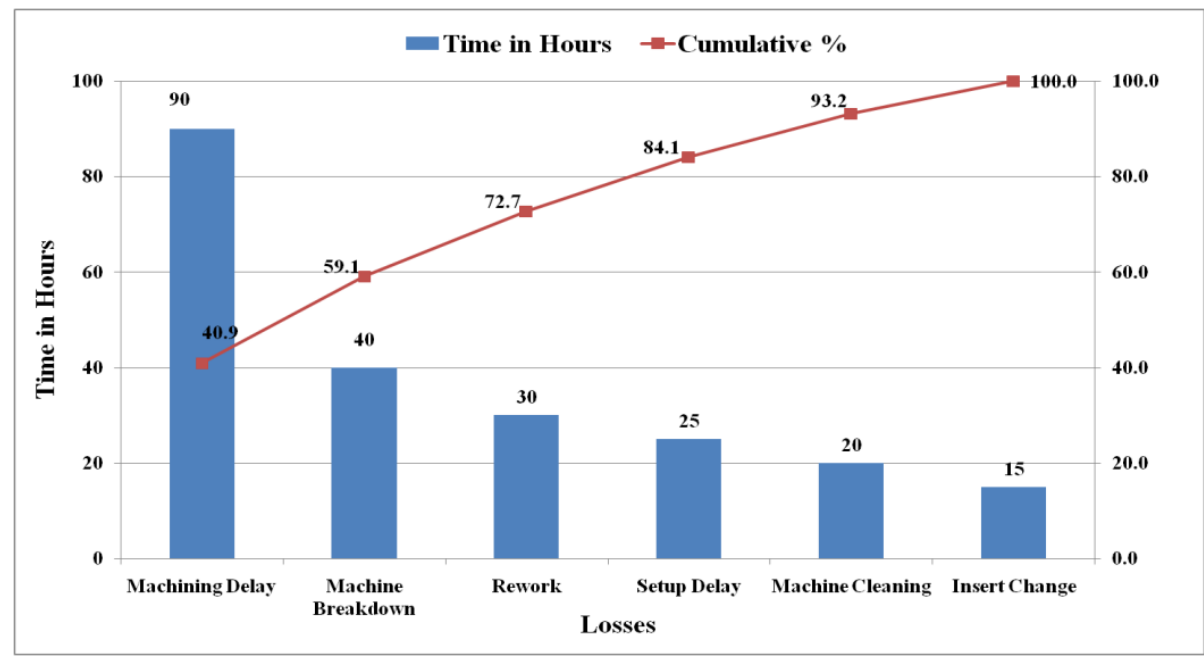

Figure 6: Pareto Chart for Time Losses 


\subsection{Total Productive Maintenance}

The fifth machine of VMC was selected as model machine for TPM activities. Initially all the problematic areas like oil leakage, wire lose connection, rotating component not having guards, coolant tank not having guards were noted. The oil leakage problem was arrested through maintenance. Similarly, guards were provided for uncovered area of rotating parts. Then cleaning started by TPM team coordinator and TPM activities were handed over to operators to carryout individually. The operators were initially trained in autonomous maintenance for implementation of TPM. A check list was prepared for follow up of the daily activities which include points like coolant level checking, hydraulic oil level checking, abnormal noise in motor, telescopic cover cleaning and Cathode Ray Tube (CRT) screen cleaning.

After implementation of TPM, the management observed changes in shop floor and employee activities towards discipline. For example, the KAIZEN activity implemented for TPM implementation in coolant tank is shown in Figure 7. Initially the machine did not have guard for coolant tank and after thorough cleaning guard has been provided. It was also observed that the coolant life had increased and rust forming in the component was eliminated after providing the guard for the coolant tank. Through autonomous maintenance the machine breakdown time was reduced by about $25 \%$ in the fifth VMC machine and it was found that there was an improvement in the machine availability after implementing the autonomous maintenance system. The actual breakdown time and the reduction of breakdown time through TPM are shown in Figure 8. It was found that the breakdown time after implementation of TPM was reduced and it was even lesser than the actual target time as was fixed for breakdown.

\begin{tabular}{|l|l|l|l|}
\hline \multicolumn{5}{|c|}{ KAIZEN } \\
\hline Team Member & $\begin{array}{l}\text { L. Perumal and } \\
\text { S. Murugan }\end{array}$ & Location/Equipment & Fifth Machine \\
\hline Problem Identified & $\begin{array}{l}\text { Machine breakdown due to } \\
\text { contamination of coolent }\end{array}$ & Remedial Action & $\begin{array}{l}\text { Coolent oil was } \\
\text { Covered }\end{array}$ \\
\hline \multicolumn{3}{|c|}{ BEFORE } & AFTER \\
\hline
\end{tabular}

Figure 7:Kaizen for TPM Implementation

\subsection{Setup Time Reduction}

As per the existing study, the setup of component makes the aligning and clamping of component by stopping the machine using plunger dial of $0.01 \mathrm{~mm}$. For this aligning and clamping it took more than 150 minutes. A new fixture was designed for aligning and clamping the component outside of the machine and is shown in Figure 9. Introduction of 
new fixture makes the component to align and clamp outside of the machine itself and kept ready for loading once the running component got completed. The fixture was kept over the surface Table with flatness of $0.2 \mathrm{~mm}$. The component was loaded over the fixture and top, front and side alignment measurements were taken by faro instrument.

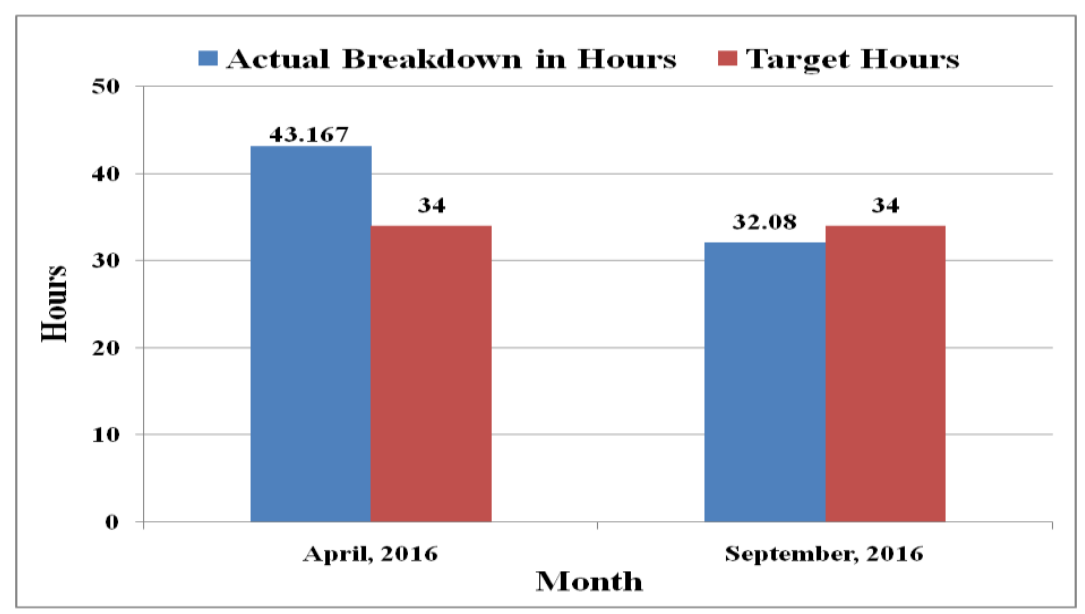

Figure 8: Breakdown Time using TPM

Top alignment was to be within $5 \mathrm{~mm}$ and front was to be kept within $2 \mathrm{~mm}$. When the alignment did not measure up to the required level then repeated measurements were done to bring the alignment within the required value. The setup time observed after implementation of new fixture is given in Table 5. The observation was made for 10 consecutive components in the fifth machine to find out the setup time and found that the possible set up time was about 36 minutes and the offset was being taken for each component. The setup time for fifth VMC machine was observed and is given in Figure 10 with the target time.

Table 5: Setup Time Observation for Fifth VMC Machine

\begin{tabular}{|c|c|c|c|c|c|c|c|c|c|}
\hline Date & Machine & Component & Operation & Shift & $\begin{array}{c}\text { Operator } \\
\text { Name }\end{array}$ & $\begin{array}{l}\text { Start } \\
\text { Time }\end{array}$ & End Time & $\begin{array}{l}\text { Total } \\
\text { Time }\end{array}$ & Remark \\
\hline $16-04-16$ & V & Mainframe & First & I & K. Vivek & 9:15 AM & 10:05 AM & $56 \mathrm{~min}$ & $\begin{array}{r}\text { Feasibility } \\
\text { Checking }\end{array}$ \\
\hline $18-04-16$ & V & Mainframe & First & II & S. Baskar & 10:10 PM & $11: 45 \mathrm{PM}$ & $35 \mathrm{~min}$ & \\
\hline 20-04-16 & V & Mainframe & First & I & K. Vivek & 2:37 PM & 3:23 PM & $47 \mathrm{~min}$ & \\
\hline $22-04-16$ & V & ame & First & III & J. Ashok & 4:20 PM & 5:05 PM & $46 \mathrm{~min}$ & \\
\hline 23-04-16 & V & Mainframe & First & II & S. Baskar & 7:15 PM & $8: 45 \mathrm{PM}$ & $85 \mathrm{~min}$ & $\begin{array}{c}\text { Crane } \\
\text { Breakdown }\end{array}$ \\
\hline $25-04-16$ & V & Mainframe & First & I & K. Vivek & 11:07 AM & $11: 42 \mathrm{AM}$ & $36 \mathrm{~min}$ & \\
\hline $27-04-16$ & V & Dectpiale & 1 & III & J. АВНIUK & $3: 22 \mathrm{AM}$ & 3:54 AM & $33 \mathrm{~min}$ & \\
\hline $28-04-16$ & $\mathrm{~V}$ & Bedplate & First & III & J. Ashok & 5:47 AM & $6: 21 \mathrm{AM}$ & $35 \mathrm{~min}$ & \\
\hline $30-04-16$ & V & Bedplate & First & III & J. Ashok & 4:15 AM & 4:47 AM & $33 \mathrm{~min}$ & \\
\hline $02-05-16$ & V & Bedplate & First & I & K. Vivek & $8: 11$ AM & $8: 48 \mathrm{AM}$ & $38 \mathrm{~min}$ & \\
\hline
\end{tabular}


Due to aligning of the component outside of the machine using faro instrument, time taken for aligning the curved components was completely eliminated. The cost of the setup time was calculated before and after implementation of new fixture which is given below.

Cost for setup time for 150 minutes

Cost for setup time with new fixture (36 minutes)

Cost saving during setup time with new fixture

$$
\begin{aligned}
& =\text { Rs } 5500 \\
& =\text { Rs } 1320 \\
& =\text { Rs } 4180
\end{aligned}
$$

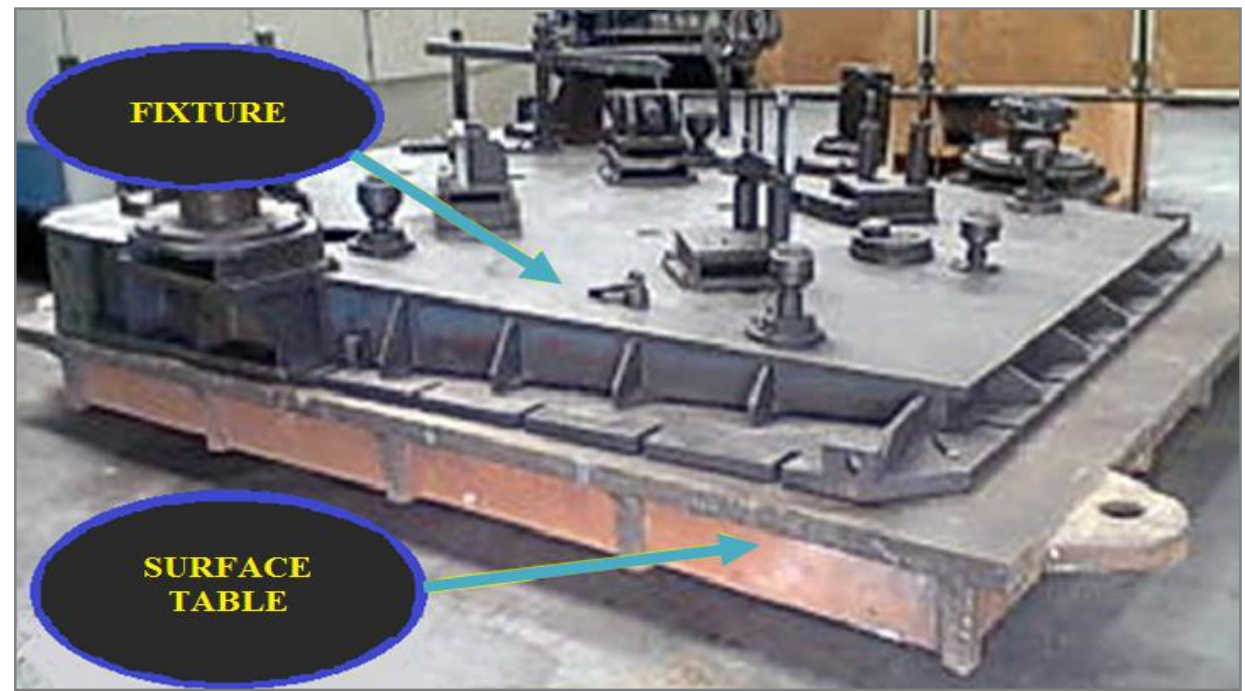

Figure 9: Proposed New Fixture

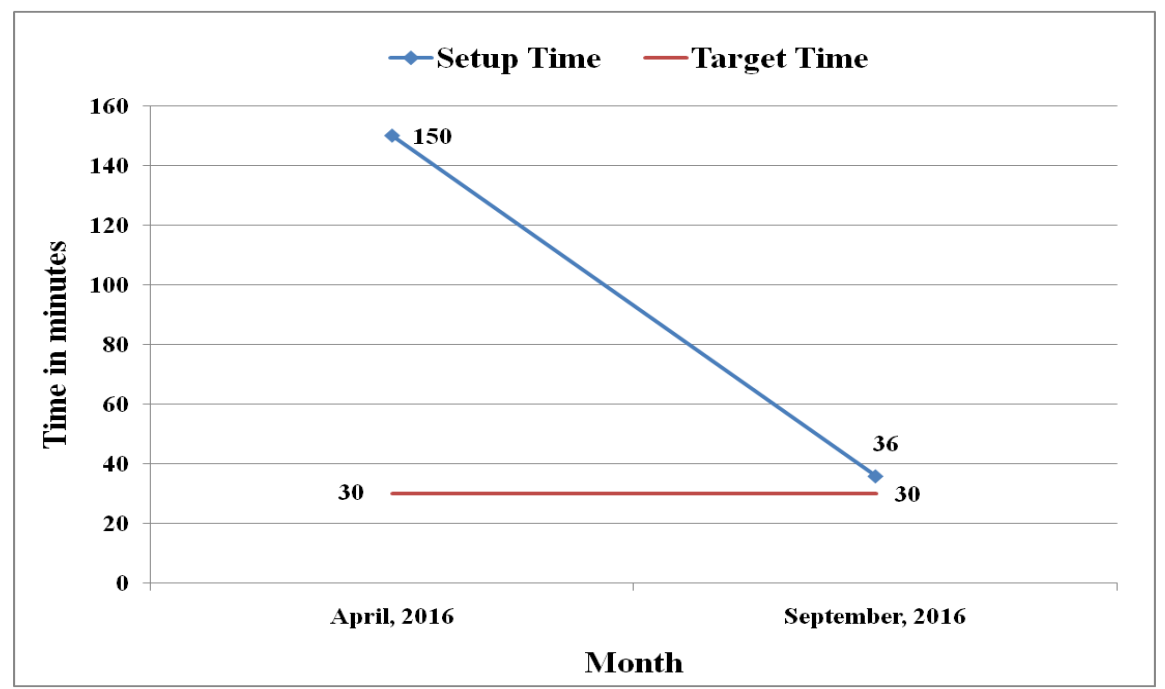

Figure 10: Setup Time for fifth VMC Machine 


\subsection{Cycle Time Reduction}

In the existing operation, the drilling, counter boring and chamfering were carried out with separate tools and after introduction of common tool all the operations were done in a single tool hence the cycle time was reduced. Similarly, by selecting appropriate parameters on speed, feed and depth of cut and tools the cycle time got reduced. Due to aligning done by faro instrument, it was enough to keep raw casting stock of $20 \mathrm{~mm}$ in all machined area in the place $30 \mathrm{~mm}$ thus a saving of $10 \mathrm{~mm}$ was made possible. The operations of drilling, counter boring and chamfering were made through a common tool in single plunge made in solid carbide material up to $18 \mathrm{~mm}$ diameter. Above $18 \mathrm{~mm}$ diameter, the insert type cutter body could be used. Figure 11 shows the common tool for $35 \mathrm{~mm}$ diameter drill size and $42 \mathrm{~mm}$ diameter counter bore. The cycle time after incorporation of common tool was reduced and all the values for each operation were observed and are given in Table 6.

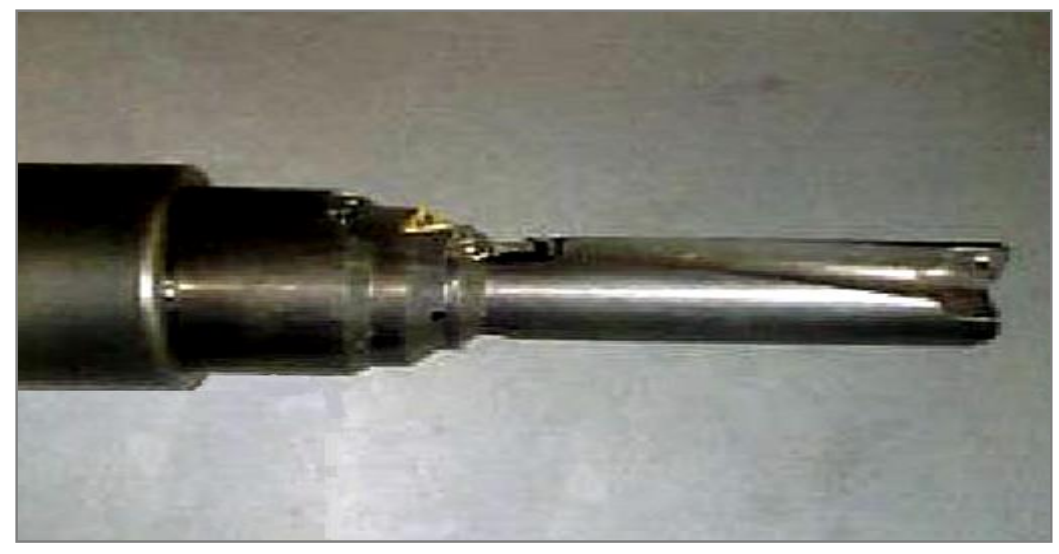

Figure 11: Common Tool for Drilling, Counter Boring and Chamfering Operations

Table 6: Cycle Time after Setting New Fixture

\begin{tabular}{|c|c|c|c|c|}
\hline \multirow{2}{*}{ Component } & \multirow{2}{*}{ Operation } & \multicolumn{2}{|c|}{ Cycle Time in Hrs } & \multirow{2}{*}{ Remarks } \\
\hline & & Before & After & \\
\hline Mainframe & First & 35 & 30 & $\begin{array}{l}\text { New fixture and Common tool were introduced } \\
\text { and Stock reduced from } 30 \text { to } 20 \mathrm{~mm}\end{array}$ \\
\hline Mainframe & Second & 27 & 25 & $\begin{array}{l}\text { Common tool introduced and stock reduced } \\
\text { from } 30 \mathrm{~mm} \text { to } 20 \mathrm{~mm}\end{array}$ \\
\hline Hub & First & 33 & 32 & New fixture was introduced \\
\hline Hub & Second & 14 & 14 & Common tool were introduced \\
\hline E Hub & First & 43 & 43 & Common tool were introduced \\
\hline E Hub & Second & 11 & 11 & Nil \\
\hline Bedplate & First & 29 & 27 & $\begin{array}{c}\text { Common tool introduced and stock reduced } \\
\text { from } 30 \mathrm{~mm} \text { to } 20 \mathrm{~mm}\end{array}$ \\
\hline Bedplate & Second & 35 & 32 & $\begin{array}{l}\text { Common tool introduced and stock reduced } \\
\text { from } 30 \mathrm{~mm} \text { to } 20 \mathrm{~mm}\end{array}$ \\
\hline
\end{tabular}

Cycle time was reduced due to introduction of new fixture, common tools and reduction of raw material stock due to faro measurement used for alignment. Figure 12 shows the cycle time reduction for mainframe. 
Cycle time of mainframe before introduction of new fixture

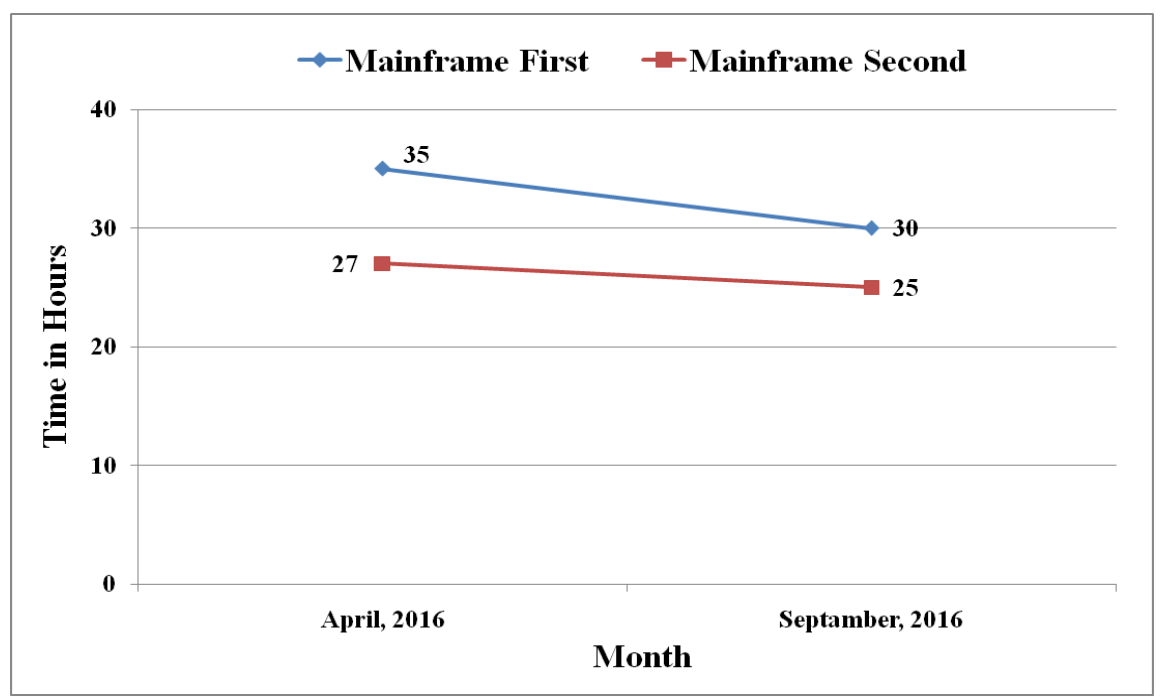

Figure 12: Mainframe Cycle Time

Table 7: Preventive Action Chart for Rework

\begin{tabular}{|c|c|c|c|c|c|}
\hline & & & & & Date: $24 / 08 / 2016$ \\
\hline Nature of Defect & Nos & $\begin{array}{c}\text { Rework } \\
\text { Time }\end{array}$ & $\begin{array}{c}\text { Rework } \\
\text { Cost (Rs.) }\end{array}$ & Reason & Preventive Action Taken \\
\hline $\begin{array}{l}\text { M36 Tab broken, } \\
\text { hance counter bore } \\
\text { damage }\end{array}$ & 2 & $650 \mathrm{mins}$ & 24500 & Worn out tab used & $\begin{array}{l}\text { Tool life monitoring chart } \\
\text { implemented and } \\
\text { recommented to change at } \\
\text { regular interval of } 80 \\
\text { minutes }\end{array}$ \\
\hline $\begin{array}{l}\text { Chamfering } \\
\text { operation was not } \\
\text { done }\end{array}$ & 1 & 300 mins & 11000 & $\begin{array}{l}\text { Chamfering program } \\
\text { made as sub program, } \\
\text { hence operator } \\
\text { missed the operation }\end{array}$ & $\begin{array}{l}\text { Program operation sequence } \\
\text { was modified }\end{array}$ \\
\hline $\begin{array}{l}\text { Surface finishing } \\
\text { was not as per } \\
\text { drawing }\end{array}$ & 1 & $220 \mathrm{mins}$ & 8500 & $\begin{array}{l}\text { Due to vibration mark } \\
\text { was found in back } \\
\text { face operation }\end{array}$ & $\begin{array}{l}\text { Final inspection checklist } \\
\text { was provided }\end{array}$ \\
\hline $\begin{array}{l}\text { Thickness was } \\
\text { measured as } 30 \mathrm{~mm} \\
\text { instead of } 31 \mathrm{~mm}\end{array}$ & 2 & $\begin{array}{l}1000 \\
\operatorname{mins}\end{array}$ & 38500 & $\begin{array}{l}\text { Crack found in } \\
140 \mathrm{~mm} \text { diameter } \\
\text { back face } \\
\text { cutter }\end{array}$ & $\begin{array}{l}\text { Dimension added in Process } \\
\text { Inspection Report }\end{array}$ \\
\hline $\begin{array}{l}\text { M36 Tab operation } \\
\text { missing }\end{array}$ & 1 & 450 mins & 17500 & $\begin{array}{l}\text { M36 tab operation } \\
\text { was carried out with } \\
\text { length tab and short } \\
\text { tab }\end{array}$ & $\begin{array}{l}\text { Program changed to do the } \\
\text { M36 tab with single tab }\end{array}$ \\
\hline $\begin{array}{l}\text { Finishing problem } \\
\text { in counter bore } \\
\text { operation }\end{array}$ & 3 & $\begin{array}{l}1300 \\
\operatorname{mins}\end{array}$ & 36500 & $\begin{array}{l}\text { Selected parameter } \\
\text { not suitable for tool }\end{array}$ & $\begin{array}{l}\text { Common tool provided with } \\
\text { correct parameter }\end{array}$ \\
\hline $\begin{array}{lrr}25 \mathrm{~mm} \text { dia } & \text { drill } \\
\text { with depth } & \text { of } \\
25+2 \mathrm{~mm} & \text { was }\end{array}$ & 2 & 220 mins & 8500 & $\begin{array}{l}\text { Due to measurement } \\
\text { was taken from raw } \\
\text { casting area }\end{array}$ & $\begin{array}{l}\text { Before drilling operation } \\
\text { component facing operation } \\
\text { done in program }\end{array}$ \\
\hline
\end{tabular}




\begin{tabular}{|l|l|l|l|l|l|}
\hline \multicolumn{5}{|c|}{} & \multicolumn{1}{|c|}{ Date: 24/08/2016 } \\
\hline Nature of Defect & Nos & $\begin{array}{l}\text { Rework } \\
\text { Time }\end{array}$ & $\begin{array}{l}\text { Rework } \\
\text { Cost (Rs.) }\end{array}$ & \multicolumn{1}{|c|}{ Reason } & Preventive Action Taken \\
\hline $\begin{array}{l}\text { measured as } \\
24.5 \mathrm{~mm}\end{array}$ & & & & \\
\hline $\begin{array}{l}244+0.2 \mathrm{~mm} \text { slot } \\
\text { GO gauge not } \\
\text { entered }\end{array}$ & 2 & 400 mins & 15000 & $\begin{array}{l}\text { Operator was not } \\
\text { checked the slot size }\end{array}$ & $\begin{array}{l}\text { Dimension was added in } \\
\text { In-Process Inspection } \\
\text { Report }\end{array}$ \\
\hline $\begin{array}{l}110 \mathrm{~mm} \text { thickness } \\
\text { face found unwash }\end{array}$ & 1 & 300 mins & 11000 & $\begin{array}{l}\text { Stock problem in raw } \\
\text { casting }\end{array}$ & $\begin{array}{l}\text { Advised to check during } \\
\text { offset }\end{array}$ \\
\hline $\begin{array}{l}\text { Due to wrong tool } \\
\text { used 12mm dia } \\
\text { counter } \\
\text { damaged bore }\end{array}$ & 1 & 220 mins & 9000 & unskilled operator & $\begin{array}{l}\text { Advised to give proper } \\
\text { training to the operator }\end{array}$ \\
\hline Total & & $\mathbf{5 0 6 0}$ & $\mathbf{1 8 0 0 0 0}$ & & \\
\hline
\end{tabular}

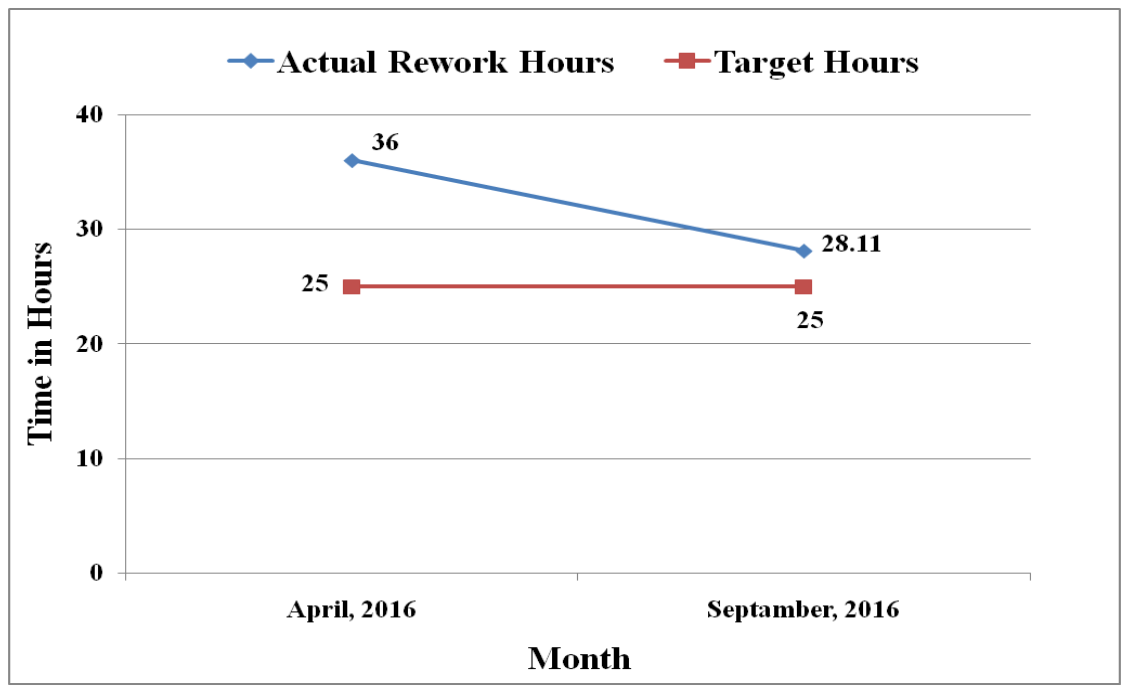

Figure 13: Reduction of Rework Time

After implementing the necessary preventive action to reduce the rework, the time taken was calculated. The rework time taken after the preventive actions was only 28.11 hours as compared to 36 hours earlier and against the target rework time of 25 hours per month/shift. On account of the preventive action, rework time was reduced by about $29 \%$ and hence this increased the quality rate of OEE. The reduction of rework time before and after implementation of preventive action is given in Figure 13.

\section{Results and Discussion}

From the existing data and analysis, it was observed that the OEE for the month of April 2016 was about $60 \%$, which required to be improved through adopting some of the best practices. For this TPM techniques were suggested and implemented in the selected CNC line. After implementation of TPM practices with autonomous and preventive maintenance actions the OEE was increased to $75 \%$ during the month of September 2016. 
The breakdown loss also got reduced by about $25 \%$ through the autonomous and preventive maintenance actions and with the introduction of a new fixture the setup time was reduced to 36 minutes from 150 minutes which was nearer to the target time. Similarly, the cycle time was reduced by about $13.5 \%$ by introduction of a common tool and also the size of the raw material stock was reduced by about $10 \mathrm{~mm}$. It was also observed that the rework time was reduced to 28.11 hours from 36 hours nearly by about $29 \%$ due to the preventive action taken at the right time. The comparative analysis of OEE for the fifth VMC machine is shown in the following Figure 14. It was clearly found that the OEE increased during September 2016 as compared to April 2016. Ultimately it was observed that the Overall Equipment Effectiveness has increased by about $15 \%$ after the suggested implementation of TPM practices.

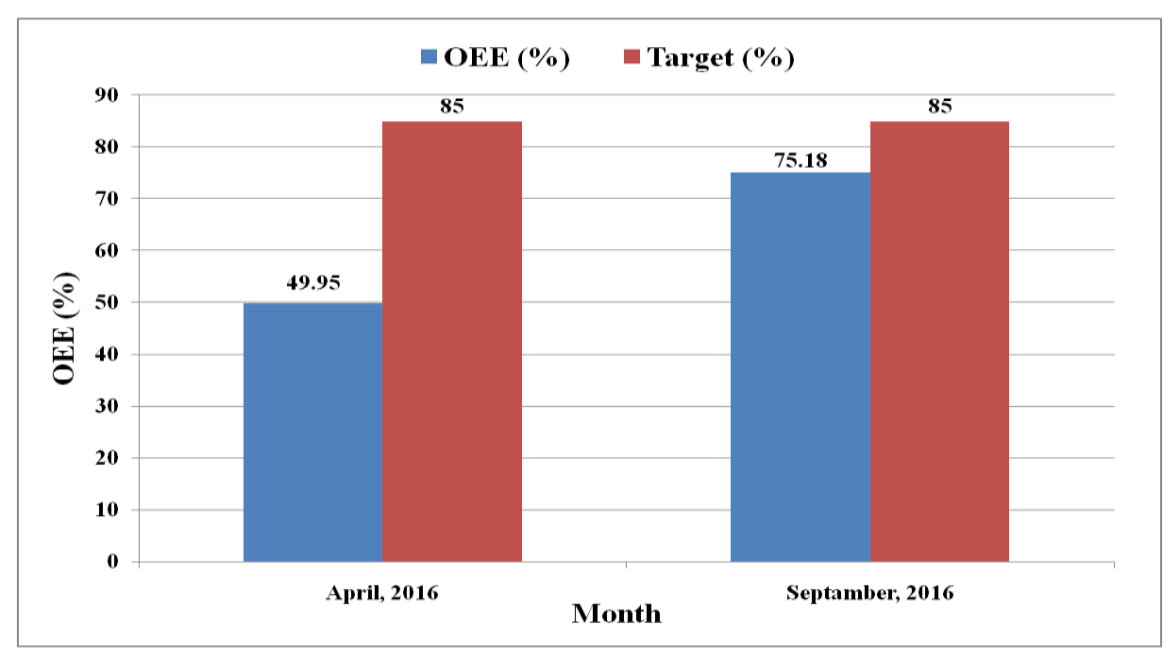

Figure 14: Comparison of OEE (\%)

From the above study and analysis made it can be clearly stated that, on implementing the TPM practices many benefits such as reduction of setup time, cycle time, machine idle time and reduction of rework time were achieved. The increase in OEE ultimately helped the company in gaining competitive edge in the industry. The TPM practices provide better work system among employees and increases the involvement of individual persons. Also it reduces the equipment deterioration and failure, maximizing production.

\section{Conclusions}

The following conclusions were arrived from the observed results of the above case study.

- Through the autonomous maintenance concept, the breakdown loss was reduced by about $25 \%$.

- The total setup time was reduced by about $75 \%$ through the introduction of new fixture.

- Through the introduction of common tool, the size of the raw material stock was reduced by about $10 \mathrm{~mm}$ which in turn reduced the cycle time by about $13.5 \%$.

- Due to the preventive actions taken based on the defects, the rework time was reduced by about $29 \%$, hence the rate of OEE also increased. 
- Finally, it was clear that through the implementation of TPM the OEE increased by about $15 \%$ and helped in meeting the customer demand.

The present work is focused to improve the effectiveness of machines which have low OEE by implementing the TPM technique and setup time reduction. It would be beneficial for future projects to find out the root causes of machine related issues and to improve the performance levels of machines and their productivity through TPM methodology and also by using TPM metrics like MTBF, MTTR, etc.

Acknowledgement: The author sincerely thanks Mr. T. G. Balachandran, Director, Administration, Dr. M.G.R. Educational and Research Institute University, Chennai-600 095, India for his support in preparing this article successfully.

\section{References}

[1]. Arunraj, K., and M. Maran.A Review of Tangible Benefits of TPM Implementation. International Journal of Applied Sciences and Engg. Research, 2014; 3(1): 171-176.

[2]. Patel, V.B., and H. R. Thakkar. Review Study on Improvement of Overall Equipment Effectiveness through Total Productive Maintenance. Journal of Emerging Technologies and Innovative Research, 2014; 1(7): 720-726.

[3]. S. Nallusamy.Enhancement of Productivity and Efficiency of CNC Machines in a Small Scale Industry using Total Productive Maintenance. International Journal of Engineering Research in Africa, 2016; 25: 119-126.

[4]. I.H. Afefy. Implementation of Total Productive Maintenance and Overall Equipment Effectiveness Evaluation. International Journal of Mechanical \& Mechatronics Engineering, 2013; 13(1): 69-75.

[5]. S. Nallusamy. Productivity Enhancement in a Small Scale Manufacturing Unit through Proposed Line Balancing and Cellular Layout. International Journal of Performability Engineering, 2016; 12(6): 523-534.

[6]. M.K. Panneerselvam. TPM Implementation to Invigorate Manufacturing Performance: An Indian Industrial Rubric. International Journal of Scientific \& Engineering Research, 2012; 3(6): 1-10.

[7]. S. Nallusamy. Lean Manufacturing Implementation in a Gear Shaft Manufacturing Company using Value Stream Mapping. International Journal of Engineering Research in Africa, 2015; 21: 231-237.

[8]. Keyser, R.S., and R.S. Sawhney.Reliability in Lean Systems. International Journal of Quality and Reliability Management, 2013; 30(3): 223-238.

[9]. Kumar, S.V.,V.G. Mani, and N. Devraj. Production Planning and Process Improvement in an Impeller Manufacturing using Scheduling and OEE Techniques. Procedia Materials Science, 2014; 5: 1710-1715.

[10]. S. Nallusamy. Frequency Analysis of Lean Manufacturing System by Different Critical Issues in Indian Automotive Industries. International Journal of Engineering Research in Africa, 2016; 23: 181-187.

[11]. Arunraj, K. and M. Maran. A Review of Tangible Benefits of TPM Implementation. International Journal of Applied Sciences and Engg. Research, 2014; 3(1): 171-176.

[12]. Samad, M.A., and M.R. Hossain. Analysis of Performance by Overall Equipment Effectiveness of The CNC Machine. APRN J. of Sci. and Tech., 2012; 2(11): 1091-1096.

[13]. S. Nallusamy. Efficiency Enhancement in CNC Industry using Value Stream Mapping, Work Standardization and Line Balancing. International Journal of Performability Engineering, 2016; 12(5): 413-422.

[14]. Puvanasvaran, A.P., C.Z. Mei, and V.A. Alagendran. Overall Equipment Efficiency Improvement using Time Study in an Aerospace Industry. Engineering Procedia Journal, 
2013; 68: 271-277.

[15]. Nallusamy, S.,G.B. Dinagaraj, K. Balakannan, and S. Satheesh. Sustainable Green Lean Manufacturing Practices in Small Scale Industries -A Case Study. International Journal of Applied Engineering Research, 2015; 10(62):143-146.

[16]. Kumar, S.V., V.G. Mani, and N. Devraj. Production Planning and Process Improvement in an Impeller Manufacturing using Scheduling and OEE Techniques. Procedia Materials Science, 2014; 5: 1710-1715.

[17]. Low, S.N., S.H. Chong, H.Y. Sim, S. Razalli, and S. Kamaruddin. Measurement of Overall Performance Effectiveness in Setup Improvement. Journal of Industrial Engineering, 2014; 2014: 1-7.

[18]. O.T.R. Almeanazel. Total Productive Maintenance and Overall Equipment Effectiveness Measurement. Jordan Journal of Mech. and Ind. Engg, 2010; 4(4): 517533.

[19]. S. Nallusamy. A Proposed Model for Lead Time Reduction During Maintenance of Public Passenger Transport Vehicles. International Journal of Engineering Research in Africa, 2016; 23:174-180.

[20]. Mori, Vipulkumar V., Y.B. Kanchava, P.A. Karetha, and M.B. Charola.Productivity Improvement by use of Time Study, Motion Study, Lean Tools and Different Strategy for Assembly of Automobile Vehicles. International Journal for Scientific Research and Development, 2015; 3(2): 2060-2065.

[21]. S. Nallusamy.A Proposed Model for Sustaining Quality Assurance using TQM Practices in Small and Medium Scale Industries. International Journal of Engineering Research in Africa, 2016; 22: 184-190.

[22]. Gabahne, L.D., M.M. Gupta, and D.R. Zanwar. Overall Equipment EffectivenessImprovement: A Case of Injection Molding Machine. The International Journal of Engineering and Sci., 2014; 3(8): 01-10.

[23]. Sahu, S., L. Patidar, and P.K.Soni.5S Transfusion to Overall Equipment Effectiveness (OEE) for Enhancing Manufacturing Productivity. International Research Journal of Engineering and Technology, 2015; 2(7): 1211-1216.

[24]. Nallusamy, S., and V. Saravanan. Enhancement of Overall Output in a Small Scale Industry through VSM, Line Balancing and Work Standardization. International Journal of Engineering Research in Africa, 2016; 26: 176-183.

Dr. S. Nallusamy is currently working as Professor and Dean in the Department of Mechanical Engineering at Dr. M.G.R. Educational and Research Institute, Chennai, India and has twenty three years of teaching and research experience. He received his B.E. (Mech.) from Madras University, M.E (Ind. Engg.) from Anna University and was awarded his Ph.D from Jadavpur University, Kolkata in the year 2009. His research interest includes Composite Material, Nanomaterials, TQM, SCM, Lean Concept etc. He has published about sixty papers in international and national journals with two text books.

Dr. Gautam Majumdar,working as Professor in the Department of Mechanical Engineering at Jadavpur University, Kolkata with thirty years of teaching and research experience. His research fields are Lean Manufacturing, TQM, SCM etc. 